\title{
32 Foreign Exchange Rates
}

Exchange rates are determined by demand and supply of currencies in the foreign exchange market. World-wide arbitrage operations ensure that world exchange rates prevail.

Demand and supply of foreign currencies depends on:

1. Visible trade balance.

2. Invisible trade balance.

3. Movements of capital: (a) long-term, $(b)$ short-term and $(c)$ speculative.

But underlying economic factors affecting trade and capital movements are:

1. Relative prices.

Cassel's Purchasing Power Parity Theory asserts:

foreign exchange price of $£$ (in $\$$ ) $=\frac{\text { USA price level }}{\text { UK price level }}$

But:

(a) all goods do not enter into international trade;

(b) indirect taxes, etc. may cause home prices to rise, but less demand means that less foreign currency is spent, so that the exchange rate improves;

(c) factors other than the price level, e.g. change in income, affect trade flows and thus the exchange rate;

(d) the theory ignores the effect of capital movements on the exchange rate.

Nevertheless, the link between the internal price level and the external value of the currency cannot be ignored because trade and capital flows tend to follow changes in relative price levels.

2. Relative money incomes.

3. Long-term investment prospects.

4. The rate of interest.

5. Expected future movements of the exchange rates.

6. Government expenditure.

7. Political factors and government policy. 